\title{
Network pharmacology approach to reveals therapeutic mecha- nism of traditional plants formulation used by Malaysia indig- enous ethnics in coronaviruses infection
}

\author{
Fui Fui Lem 1,*, Dexter Jiunn Herng Lee ${ }^{2}$, Fong Tyng Chee ${ }^{3}$, Su Na Chin ${ }^{4}$, Kai Min Lin ${ }^{5,6}$ and Chee Wei Yew ${ }^{2, *}$ \\ 1 Clinical Research Centre, Hospital Queen Elizabeth, Ministry of Health Malaysia, 88586 Kota Kinabalu, \\ Sabah, Malaysia; lemfuifui02@gmail.com; lemfuifui@moh.gov.my \\ 2 Biotechnology Research Institute, Universiti Malaysia Sabah, Jalan UMS, 88400 Kota Kinabalu, Sabah, Ma- \\ laysia; dexlee8@gmail.com; cheewei.yew@ums.edu.my \\ 3 Faculty of Sustainable Agriculture, Universiti Malaysia Sabah, Locked Bag No 3, 90509 Sandakan, Sabah, \\ Malaysia; ftchee@ums.edu.my \\ 4 Faculty of Science and Natural Resources Universiti Malaysia Sabah, Jalan UMS, 88400 Kota Kinabalu, Sa- \\ bah, Malaysia; chinsuna@ums.edu.my \\ 5 Cambridge Institute for Medical Research, University of Cambridge, the Keith Peters Building, Cambridge \\ Biomedical Campus, Hills Road, Cambridge CB20XY; km153@cam.ac.uk \\ 6 Department of Infectious Disease, Imperial College London, Exhibition Rd, South Kensington, London SW7 \\ 2BX, United Kingdom; kml53@cam.ac.uk \\ * Correspondence: lemfuifui@moh.gov.my (F.F. Lem); cheewei.yew@ums.edu.my (C.W. Yew)
}

\begin{abstract}
Network pharmacology analysis can act as a strategy to identify the pharmacological effect of plant-based bioactive compounds against coronavirus diseases. This study aimed to investigate the potential pharmacological mechanism of a local ethnomedicine (Costus speciosus, Hibiscus rosa-sinensis and Phyllanthus niruri) of Northern Borneo against coronaviruses known as CHP. Compounds in CHP were extracted from databases and screened for their oral bioavailability and druglikeness before a compound-target network was built. Furthermore, the protein-protein interaction network and pathway enrichment were constructed and analyzed. A compound-target network consisting of 48 putative bioactive compounds targeting 587 candidate genes was identified. A total of 186 coronavirus-related genes were extracted and TP53, STAT3, HSP90AA1, STAT1 and EP300 were predicted to be the key targets. Notably, mapping of these target genes into the target-pathway network illustrated that functional enrichment was on viral infection and regulation of inflammation pathways. Urinatetralin is predicted, for the first time, as a bioactive compound that solely targets STAT3. The results from this study indicate that compounds present in CHP employ STAT3 and its connected pathways as the mechanism of action against coronaviruses. In conclusion, urinatetralin should be further investigated for its potential application against coronavirus infections.
\end{abstract}

Keywords: Network pharmacology; Malaysia indigenous ethnics; coronaviruses infection; therapeutic mechanism

\section{Introduction}

Over the last 20 years, different coronaviruses have emerged and caused outbreaks such as severe acute respiratory syndrome (SARS), Middle East respiratory syndrome (MERS) and the current novel coronavirus disease (COVID-19). These viruses, which are named as SARS-CoV-1, MERS-CoV and SARS-CoV-2, respectively, are believed to have zoonotic origins and are transmitted among the human populations (El-kafrawy et al., 2019; Wang et al., 2005; Zhou et al., 2020). In just a short outbreak of one year, the number of COVID-19 cases has exceeded 100 million, causing deaths of more than 2.2 million individuals by the end of January 2021. The (alveolar epithelial (AT1) cells) bronchial transient secretory cells on the lower respiratory tracts are infected (Lukassen et al., 2020), causing acute inflammation and subsequent pneumonia that could inflict death. Severe 
pneumonia is induced by the uncontrolled overproduction of multiple inflammatory cytokines, which leads to lung injury and acute respiratory distress syndromes (Huang et al., 2020; Z. Xu et al., 2020; X. Yang et al., 2020). The majority of the deceased victims are older adults or those who were pre-diagnosed with diabetes, hypertension, rheumatic, cardiac and kidney diseases (Niu et al., 2020; Palmieri et al., 2020; Silva et al., 2020; Wang et al., 2020; Xiang et al., 2020; Zhou et al., 2020). An effective therapy is still needed; athough some antiviral drugs such as chloroquine (blocking the binding of virion to cell receptor), lopinavir-ritonavir (a HIV protease / CYP450 inhibitor) and remdesivir (an adenosine analogue blocking viral RNA replication) have been repurposed and intensively tested, their efficacy remains to be confirmed in clinical treatment (Cao et al., 2020; Colson et al., 2020; C. J. Gordon et al., 2020; Ko et al., 2020). As such, there is an urgency to find potential drug candidates that effectively act against coronavirus diseases.

Although the genome of SARS-CoV-2 only shares $79.5 \%$ and $50 \%$ amino acid sequence identity with SARS-CoV-1 and MERS-CoV, respectively (Lu et al., 2020), they have a common genomic structure and functional proteins; for example, those that mediate the entry (Spike glycoprotein, S), replication (RNA-dependent RNA polymerase, RdRp) and assembly (envelope protein, E; membrane protein, M; nucleocapsid protein, N) of the viruses in the host cells (Lu et al., 2020; Zhou et al., 2020; Zumla et al., 2016). However, the key differences at the receptor-binding domain of the Spike $(S)$ protein between SARSCoV-1 and SARS-CoV-2, which form a complex with the host cell receptor, angiotensinconverting enzyme 2 (ACE2), could have attributed to its higher potential of transmissibility in comparison with other coronaviruses (Hu et al., 2021; X. Xu et al., 2020). Nevertheless, subsequent network analyses of the virus-host protein-protein interactome have revealed shared pan-coronavirus viral-disease molecular mechanisms on transmission and replication (D. E. Gordon et al., 2020a). These interacting proteins could be new therapeutic targets for repurposed drugs or discovery of new bioactive molecules (Chassey et al., 2014; D. E. Gordon et al., 2020b).

The spread of the SARS-CoV-2 virus could be stopped by reaching herd immunity after the majority of human beings are vaccinated. However, the emergence of coronaviruses over the last 20 years, which are notorious for inducing acute respiratory distress syndrome (ARDS), should be taken as an alarming sign as we know that these viruses are spillovers from reservoirs or intermediate hosts that are encountered through human activities. As vaccines are specifically designed to target prevalent strains of viruses, spontaneous mutations could render the vaccines ineffective. Although the covid-19 vaccines have become readily available in just a year time, which is the fastest in the human history, sufficient distribution of the vaccines and completion of the subsequent vaccination programs may take another year to be completed. Taking covid-19 as an example, millions of lives could be claimed during this period. As such, natural products with polypharmacological actions should be investigated and mined as a preparedness strategy for the next emerging coronavirus.

Medicinal plants serve as a huge reservoir of bioactive molecules, contributing to almost $25 \%$ of modern drugs (Orhan, 2012). A number of plant-based traditional Chinese medicines such as Hanshiyi and Qinfei Paidu decoctions have already been clinically tested to reduce the transition of mild symptoms to severe ones in COVID-19 patients, which has been attributed to their anti-inflammatory protection effect (Tian et al., 2020; $X i n$ et al., 2020). Considering the rich biodiversity of plants found in the tropical rainforest of northern Borneo, natural products extracted from plant-based ethnomedicines that are traditionally used by a local indigenous community, Kadazan-Dusun, could be explored for their medicinal potentials. For example, the root of Alstonia scholaris, which has been used for treating fever by the local community (Ahmad and Holdsworth, 2003), has been found to inhibit $\gamma$ coronavirus through the compounds alstotides extracted from the plants (Nguyen et al., 2015). In this study, an ethnomedicine which is a cooked tea made up of three local plants known as Sibhu-sibhu (Costus speciosus Sm.), Tongkuango (Hibiscus rosa-sinensis L.) and Nipon-nipon (Phyllanthus niruri L.) (subsequently 
abbreviated as CHP), was investigated for its antiviral effect. It has traditionally been used to relieve flu-like symptoms such as fever, cough and shortness of breath. Furthermore, the use of the individual plants (as summarized in Table 1) for the relief of asthma, hypertension or even malaria infection (Ahmad and Holdsworth, 2003; Kodoh et al., 2017) has been documented in other indigenous communities; however, there is a lack of scientific evidence for their therapeutic effect. Furthermore, previous screening of their biochemical properties demonstrated that the individual plant extracts of each possess anti-inflammatory (IH, 1966), anti-viral (Álvarez et al., 2012; Forero et al., 2008; Naik and Juvekar, 2003; Venkateswaran et al., 1987; Wahyuni et al., 2019; Xiang et al., 2008) and anti-microbial effects (Saraf, 2010). As the targeted symptoms are similar to those associated with coronavirus infection and comorbidities, the synergistic effects of the bioactive compounds found in the CHP ethnomedicine deems further analysis through a network pharmacology approach.

In line with this, the aim of this study was to, first, predict the bioactive molecules from the known chemical compounds present in each plant. Second, the target proteins from both coronaviruses or human hosts, were determined from databases and published papers. Next, the compound-target network was constructed and then mapped to the protein-protein interaction network of a human host and coronaviruses, for the identification of molecular pathways modulated by the bioactive compounds. The approach of network pharmacology can be used to predict the synergistic effects of the bioactive compounds (Fang et al., 2018) found in CHP on multiple cellular protein targets that mediate numerous biological pathways involving viral infection and host immune defense. As such, the mechanism of actions of this ethnomedicine against coronavirus infection was described.

Table 1. Traditional use of plants part in treating viral-infection related clinical symptom by indigenous ethnic people in Northern Borneo.

\begin{tabular}{|c|c|c|c|}
\hline Plant name & Traditional usage & Treatment & References \\
\hline \multirow{5}{*}{$\begin{array}{l}\text { (Costus specio- } \\
\text { sus (J. Koenig) } \\
\quad \text { Sm.) }\end{array}$} & Peeled stems are steeped in hot wa- & Asthma & (Ahmad \\
\hline & ter as drinking water & Influenza & Holdsworth, 2003) \\
\hline & Rhizomes are boiled as tea & cough & (Ahmad et al., 1994) \\
\hline & Root & Fever & (Institute Medical Re- \\
\hline & & Cough & search, 2018) \\
\hline \multirow{3}{*}{$\begin{array}{c}\text { Tongkuango } \\
\text { (Hibiscus rosa- } \\
\text { sinensis L.) }\end{array}$} & Sap from shoots is drunk as water & Asthma & (Ahmad \\
\hline & & & Holdsworth, 2003) \\
\hline & $\begin{array}{l}\text { Flowers are boiled and packed as } \\
\text { patch }\end{array}$ & Yello & al., 2017) \\
\hline \multirow{3}{*}{$\begin{array}{l}\text { Nipon-nipon } \\
\text { (Phyllanthus ni- } \\
\text { ruri L.) }\end{array}$} & Plants are pounded into a paste & Fever & (Ahmad \\
\hline & and squeezed for the juice & Malaria & Holdsworth, 2003) \\
\hline & & Hypertension & \\
\hline
\end{tabular}

\section{Results}

\subsection{Putative bioactive compounds and targeted genes}

A total of 239 compounds were collected from C (81), H (109) and P (48) (supplementary Table 1). After filtering with the ADME criteria, a total of 49 compounds constituting 18 (C), $17(\mathrm{H})$ and $14(\mathrm{P})$ compounds, respectively, were considered as bioactive with drug properties, as summarized in Table 2 according to the OB and DL criteria set in section 4.2 .

Table 2. The list of putative bioactive compounds found in the CHP ethnomedicine. 


\begin{tabular}{|c|c|c|}
\hline Plant species & Molecule & Formula \\
\hline \multirow{18}{*}{$\begin{array}{l}\text { Costus speciosus } \\
\text { (J.Koenig) Sm (C) }\end{array}$} & 1,8-Cineole & $\mathrm{C} 10 \mathrm{H} 18 \mathrm{O}$ \\
\hline & 3-(4-hydroxyphenyl)-2E propenoate & $\mathrm{C} 9 \mathrm{H} 8 \mathrm{O} 3$ \\
\hline & Borneol & $\mathrm{C} 10 \mathrm{H} 18 \mathrm{O}$ \\
\hline & Bornyl acetate & $\mathrm{C} 12 \mathrm{H} 20 \mathrm{O} 2$ \\
\hline & Camphor & $\mathrm{C} 10 \mathrm{H} 16 \mathrm{O}$ \\
\hline & Caryophyllene oxide & $\mathrm{C} 15 \mathrm{H} 24 \mathrm{O}$ \\
\hline & Costunolide & $\mathrm{C} 15 \mathrm{H} 20 \mathrm{O} 2$ \\
\hline & Coumarin & $\mathrm{C} 9 \mathrm{H} 6 \mathrm{O} 2$ \\
\hline & Eremanthin & $\mathrm{C} 15 \mathrm{H} 18 \mathrm{O} 2$ \\
\hline & Gramine & C11H14N2 \\
\hline & Humulene epoxide II & $\mathrm{C} 15 \mathrm{H} 24 \mathrm{O}$ \\
\hline & lauric acid & $\mathrm{C} 12 \mathrm{H} 24 \mathrm{O} 2$ \\
\hline & Linalool & $\mathrm{C} 10 \mathrm{H} 18 \mathrm{O}$ \\
\hline & Terpinen-4-ol & $\mathrm{C} 10 \mathrm{H} 18 \mathrm{O}$ \\
\hline & vanillin & $\mathrm{C} 8 \mathrm{H} 8 \mathrm{O} 3$ \\
\hline & zerumbone & $\mathrm{C} 15 \mathrm{H} 22 \mathrm{O}$ \\
\hline & $\alpha$-Terpineol & $\mathrm{C} 10 \mathrm{H} 18 \mathrm{O}$ \\
\hline & $\beta$-Eudesmol & $\mathrm{C} 15 \mathrm{H} 26 \mathrm{O}$ \\
\hline \multirow{17}{*}{$\begin{array}{l}\text { Hibiscus-sinensis rosa } \\
\text { L. (H) }\end{array}$} & 10-oxo methyl ester & $\mathrm{C} 12 \mathrm{H} 22 \mathrm{O} 3$ \\
\hline & 2, 2, 4-trimethyl 3- pentanone & $\mathrm{C} 8 \mathrm{H} 16 \mathrm{O}$ \\
\hline & 2-cyclopentylethanol & $\mathrm{C} 7 \mathrm{H} 14 \mathrm{O}$ \\
\hline & 4- trifluoroacetoxyoctane & $\mathrm{C} 10 \mathrm{H} 17 \mathrm{~F} 3 \mathrm{O} 2$ \\
\hline & 7-Formylbicyclo(4.1.0) heptanes & $\mathrm{C} 8 \mathrm{H} 12 \mathrm{O}$ \\
\hline & 8-Nonynoic & $\mathrm{C} 9 \mathrm{H} 14 \mathrm{O} 2$ \\
\hline & 9-decynoic acids & $\mathrm{C} 10 \mathrm{H} 16 \mathrm{O} 2$ \\
\hline & amylnitrite & C5H11NO2 \\
\hline & anthocyanin & $\mathrm{C} 15 \mathrm{H} 11 \mathrm{O}$ \\
\hline & dec-9-ynoic acid methyl ester & $\mathrm{C} 11 \mathrm{H} 18 \mathrm{O} 2$ \\
\hline & decanoic acid & $\mathrm{C} 10 \mathrm{H} 20 \mathrm{O} 2$ \\
\hline & lauric acid & $\mathrm{C} 12 \mathrm{H} 24 \mathrm{O} 2$ \\
\hline & niacin & $\mathrm{C} 6 \mathrm{H} 5 \mathrm{NO} 2$ \\
\hline & non-8-ynoic acid methyl ester & $\mathrm{C} 10 \mathrm{H} 16 \mathrm{O} 2$ \\
\hline & nonanoic acid & $\mathrm{C} 9 \mathrm{H} 18 \mathrm{O} 2$ \\
\hline & octanoic acid & $\mathrm{C} 8 \mathrm{H} 16 \mathrm{O} 2$ \\
\hline & undecanoic acid & $\mathrm{C} 11 \mathrm{H} 22 \mathrm{O} 2$ \\
\hline \multirow{5}{*}{$\begin{array}{l}\text { Phyllanthus niruri L. } \\
\text { (P) }\end{array}$} & Cubebin dimethyl ether & $\mathrm{C} 22 \mathrm{H} 26 \mathrm{O} 6$ \\
\hline & Estradiol & $\mathrm{C} 18 \mathrm{H} 24 \mathrm{O} 2$ \\
\hline & hinokinin & $\mathrm{C} 20 \mathrm{H} 18 \mathrm{O} 6$ \\
\hline & hypophyllanthin & $\mathrm{C} 24 \mathrm{H} 30 \mathrm{O} 7$ \\
\hline & isolintetralin & $\mathrm{C} 23 \mathrm{H} 28 \mathrm{O} 6$ \\
\hline
\end{tabular}




\begin{tabular}{cc}
\hline lintetralin & $\mathrm{C} 23 \mathrm{H} 28 \mathrm{O} 6$ \\
\hline methyl-salicylate & $\mathrm{C} 8 \mathrm{H} 8 \mathrm{O} 3$ \\
\hline Nirtetralin & $\mathrm{C} 24 \mathrm{H} 30 \mathrm{O} 7$ \\
\hline Norsecurinine & $\mathrm{C} 12 \mathrm{H} 13 \mathrm{NO} 2$ \\
\hline Phyllnirurin & $\mathrm{C} 20 \mathrm{H} 22 \mathrm{O} 5$ \\
\hline phyllochrysine & $\mathrm{C} 13 \mathrm{H} 15 \mathrm{NO} 2$ \\
\hline phyltetralin & $\mathrm{C} 24 \mathrm{H} 32 \mathrm{O} 6$ \\
\hline Securinine & $\mathrm{C} 13 \mathrm{H} 15 \mathrm{NO} 2$ \\
\hline Urinatetralin & $\mathrm{C} 22 \mathrm{H} 24 \mathrm{O} 6$
\end{tabular}

\subsection{CHP compound-target genes network analysis}

A total of 588 non-redundant targets contributing C (241), H (270) and P (363) were predicted (Figure 1a). Four compounds, octanoic acid and amylnitrile from $\mathrm{H}$ and isolintetralin and lintetralin from $\mathrm{P}$, did not fulfil the prediction criteria. Only the predicted targets with probability $>0$ were included in the compound-target network (Figure $1 b$ ) for high confidence of the predicted target from the databases.

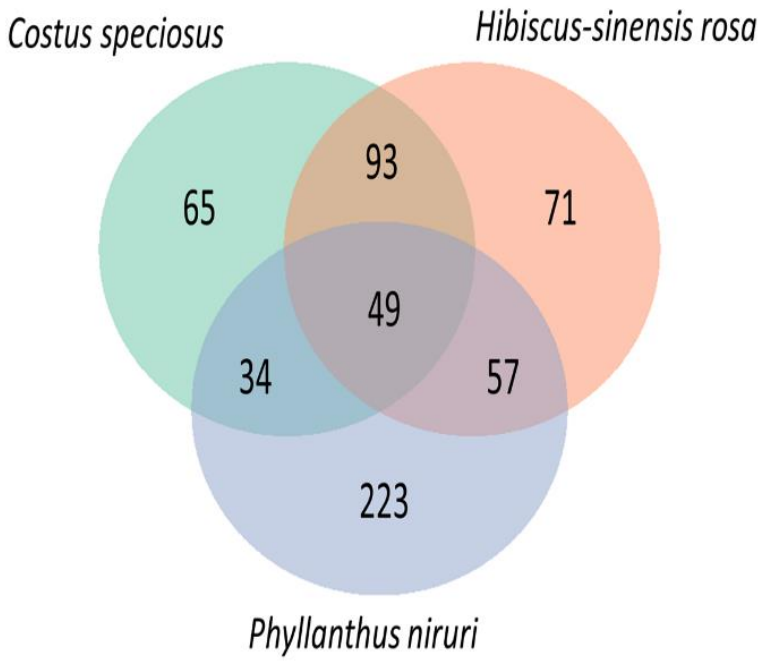

(a) 


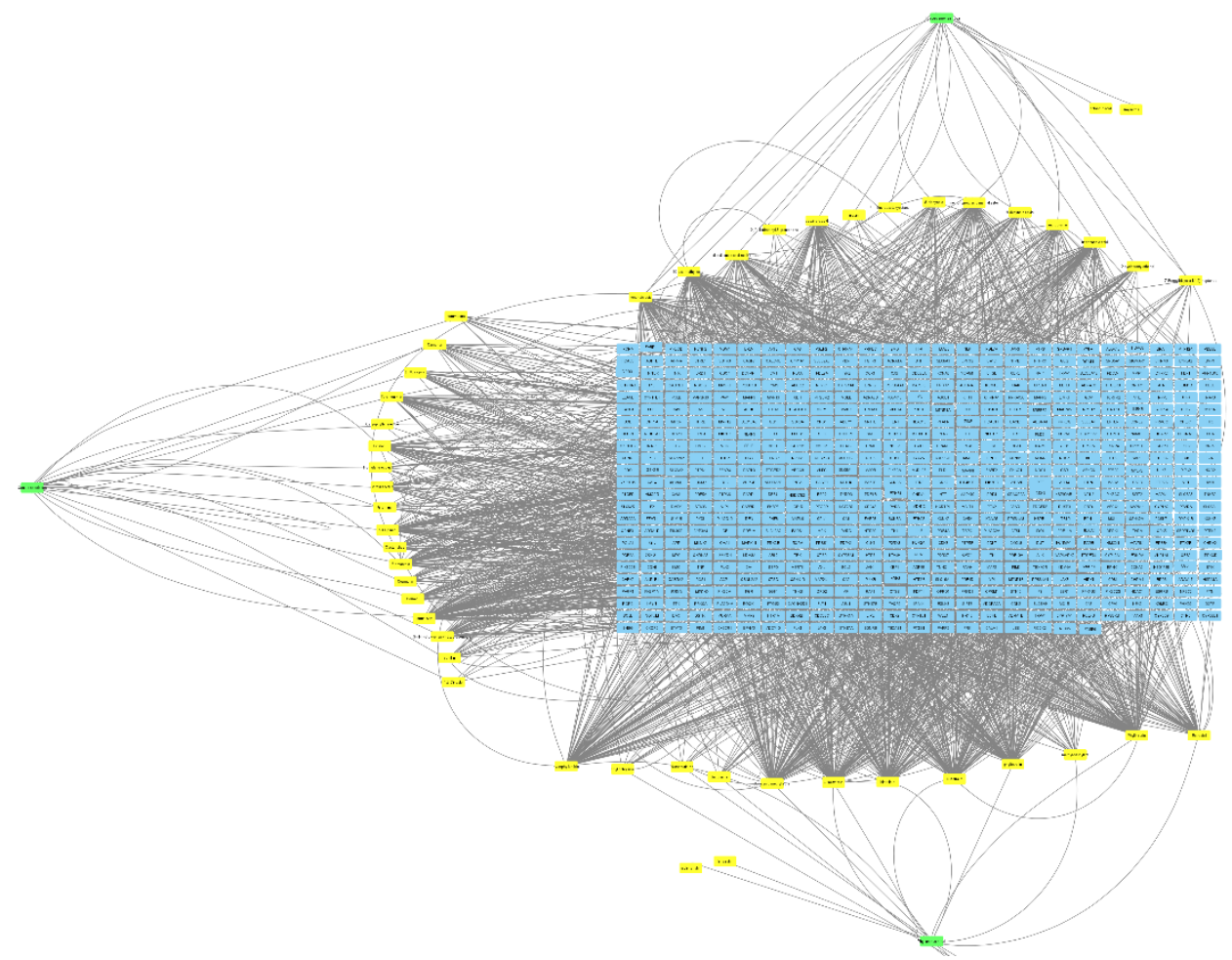

(b)

Figure 1. Analysis of compound-target network constructed based on $49 \mathrm{CHP}$ bioactive compounds and 588 putative target genes. (a) The Venn diagram shows common and unique number of targets by compounds from different plants. (b) The illustration of a compound-target network.

2.3 Mapping of the coronavirus-related genes to protein-protein interaction network of the target genes

A total of 186 coronavirus-related genes were extracted from a public database. These genes were then compiled with the CHP compound targets. Predicted targets with the highest confidence value of 0.98 were used to construct the compound-target proteinprotein interaction network (PPI). The resulting PPI was made up of 721 nodes linked by 421 edges, with an average node degree of 1.17 and average local clustering coefficient of 0.228 . Notably, MCL clustering of all nodes grouped 25 clusters in the PPI network (Figure 2). To better understand the mechanism of CHP in coronavirus, PPI was constructed and their topological properties such as betweenness centrality (BC) and connectivity degree were analyzed, the fundamental measures nodes in network theory (Barabási et al., 2011), using Network Analyzer plugin in Cytoscape Version 3.8. Analyses of the node degree and betweenness centrality (data shown in Supplementary Table 2) revealed 20 hub nodes and 20 bottleneck nodes, and five key genes were identified from the hub/bottleneck nodes, as shown in Table 3. Analyses of PPI predicted that TP53 (31) and STAT3 (24) are the hub nodes attributed to the largest degree of connectivity with other genes (Supplementary Table 2). In addition, these two genes were also predicted to be key proteins (i.e., with high degree of BC) together with HSP90AA1, STAT1 and EP300 as the key proteins that we identified from the PPI, which are the pivotal genes that correspond to the pathogenesis of the coronavirus infection. In the meantime, bottleneck nodes, which are known to lead to network "traffic" chaos, were also identified: F3, CNR1, DRD2, SMO, SQLE and F2. We also found that TP53 and STAT3 were also defined as bottleneck nodes since hub and bottleneck nodes show a tendency to be indistinguishable (Charitou et al., 2016). In this study, we focused on proteins with large degree and high BC; i.e., TP53, STAT3, HSP90AA1, STAT1 and EP300 as the key proteins. 


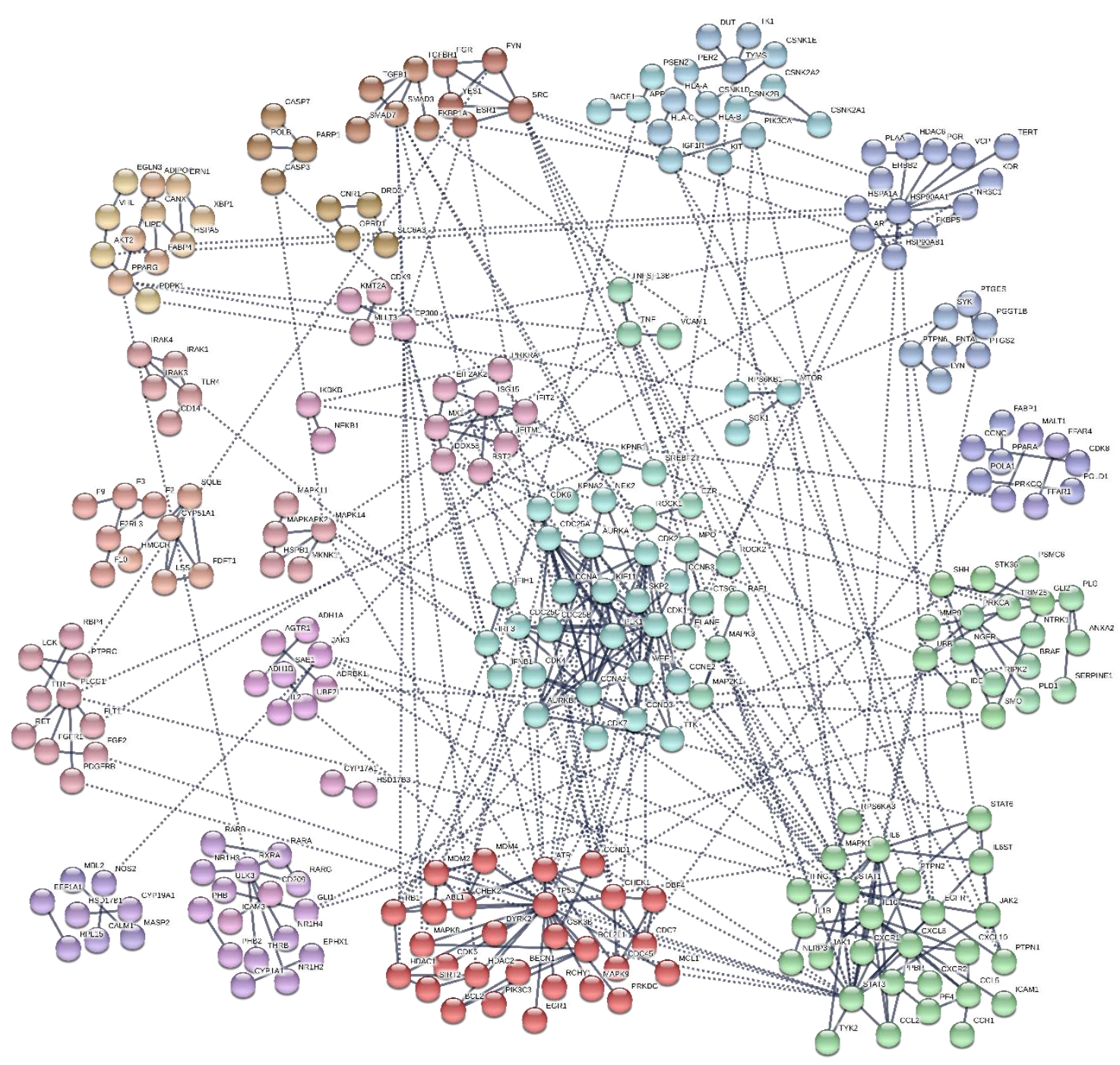

Figure 2. Constructed protein-protein interaction network from the compiled predicted targets of CHP and coronavirusrelated genes. MCL clustering resulted in 25 clusters with 2 main subclusters containing hub nodes of TP53 (red) and STAT3 (green)

Table 3. Hub and bottleneck nodes in PPIN.

\begin{tabular}{cl}
\hline \multirow{2}{*}{ Hub nodes } & TP53, STAT3, CDK1, CCNA2, HSP90AA1, CDK2, STAT1, CDC25A, SRC, \\
& IL6, CCL8, CCND1, IL10, TNF, EP300, PLK1, AURKA, CHEK1, ISG15, \\
& RXRA \\
\hline \multirow{2}{*}{ Bottleneck nodes } & HLA-A, KPNB1, F3, CNR1, DRD2, SMO, SQLE, F2, TP53, GLI1, STAT3, \\
& GRK2, HSP90AA1, MAPK14, EP300, STAT1, GLI2, TNF, PPARG, IRF3 \\
\hline Key genes & TP53, STAT3, HSP90AA1, STAT1, EP300 \\
\hline
\end{tabular}

2.4 Mechanism-of-action of anti-coronavirus indications mediated by bioactive compounds

Gene ontology (GO) analysis revealed that most of the existing potential targets were enriched in the cellular response to chemical stimulus, cellular response to organic substances, regulation of biological quality, response to oxygen-containing compound and positive regulation of biological process (Figure 3). GO analyses showed that among the top 20 enriched virus-related biological processes (Figure 4a) were regulation of defense response $(2.60 \times 10-42)$, regulation of $\mathrm{T}$ cell activation $(1.38 \times 10-17)$, response to virus 
(4.60x10-13), defense response to virus $(7.44 \times 10-07)$ and regulation of interleukin-6 production (5.83x10-06). Cell, cytoplasm, membrane and intracellular components were the cellular components that most of the target genes involved (Figure 3b). Notably, Kaposi's sarcoma-associated herpesvirus infection (1.90x10-26), influenza A (1.27x10-25), hepatitis $B(5.55 \times 10-25)$ and Epstein-Barr virus infection (3.79x10-24) were identified among the top 20 KEGG pathways, as demonstrated in Figure 3c. As shown in Figure 3d, molecular functions that are mostly involved by $\mathrm{CHP}$ are catalytic activity and drug binding with $\mathrm{p}$-value of 7.31x10-81 and 2.42x10-77, respectively.

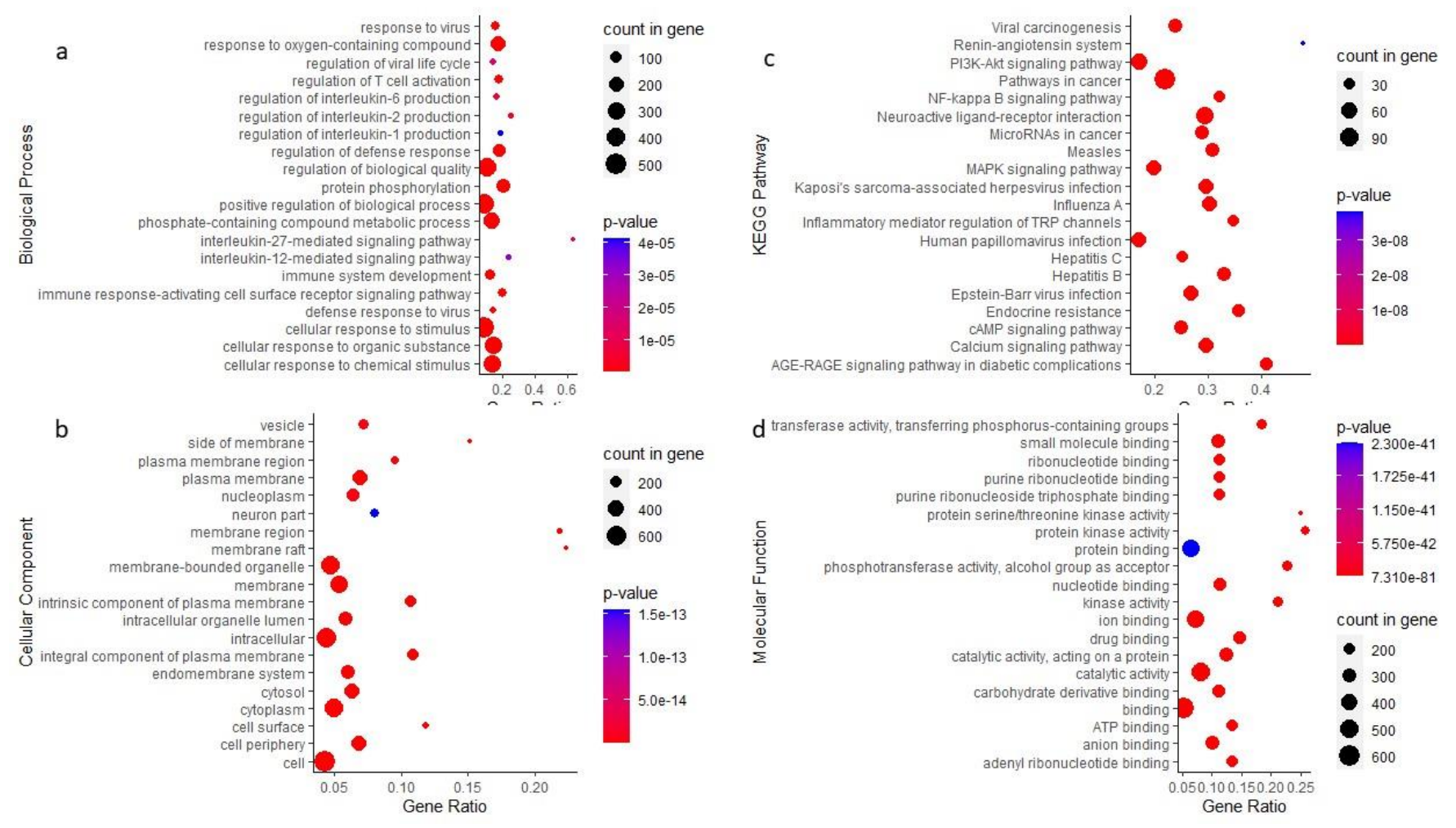

Figure 3. Enrichment analysis of CHP and coronaviruses target gene in accordance with (a) biological process, (b) cellular component, (c) KEGG pathway and (d) molecular function.

\section{Discussion}

To the best of our knowledge, this is the first study to postulate the mechanism of action of CHP, which has been traditionally used by the indigenous Kadazan-Dusun people of Borneo, against coronavirus infection using a network pharmacology approach. Analysis of pathway enrichment showed that majority of the targeted proteins play roles in membrane/cell surface, membrane binding, signal transduction, phosphorylation, kinases activities, viral response, regulation of viral cell cycle, cytokine signaling, regulation of inflammation and activation of $\mathrm{T}$ cells (Figure 3). Notably, these pathways illustrate general mechanisms of viral pathogenesis and induction of an immunity response caused by coronaviruses (D. E. Gordon et al., 2020a). This indicates that multiple bioactive compounds in the CHP ethnomedicine could act in synergy to mediate cellular response against infection of coronaviruses and subsequent induction of immune defense mechanisms. Nevertheless, it should be noted that different medicinal plants could employ a different mechanism of action against coronavirus. For instance, Qingfei paidu decoction was proposed to mediate anti-inflammation induced by Covid-19 via the Toll-like (TLR) signaling pathway (R. Yang et al., 2020) and Shuang Huang Lian Kou fu ye mitigate the Covid-19 through inhibiting the angiotensin-converting enzyme (ACE) (Lem et al., 2021).

The results from this study suggest that CHP employs STAT3 and its connected pathways as the mechanism of action against coronaviruses. According to PPI, the STAT3 
protein was predicted to be a hub gene forming a subcluster and connected directly to MAPK1, TP53, IL6, HSP90AA1 and indirectly to EP300 and STAT1, which are also putative key genes as inferred by the network analysis. STAT3 has been found to be versatile and plays a central role in response to viral infection, immunity such as chemokine signaling pathway, and neutrophil trafficking during acute inflammation (Chang et al., 2018; Fielding et al., 2008; Kim et al., 2019; Shamir et al., 2020). Coronaviruses such as SARS$\mathrm{CoV}$ cause SARS infection by mediating viral replication in target cells and immune response. It activates the p38 MAPK pathway, which induces STAT3 dephosphorylation at Tyr705, which eventually promotes SARS-CoV replication (Mizutani et al., 2004). In addition, the IL-6/STAT3 pathway promotes inflammation. IL-6 is a classic pro-inflammatory cytokine that signals through STAT3 as part of the acute phase response that aims to attract macrophages that destroy the infected cells and clearance of virus particles (Choy and Rose-John, 2017; Suarez et al., 2018). Acute respiratory distress syndrome (ARDS), which is the inflammatory injury to the alveola-capillary membrane that leads to acute pneumonia and respiratory insufficiency, is regarded as the hallmark of immune-mediated clinical consequence after infection by SARS-CoV-2 (nCoV-2019) (Huang et al., 2020; $\mathrm{Z}$. Xu et al., 2020). ARDS is the ultimate result of a cytokine storm (Coperchini et al., 2020). As such, the mechanism of action acting against STAT3 could be further explored as a potential drug target for inflammation (Hu et al., 2019).

Furthermore, mapping of the compound-target proteins to coronavirus-related genes indicated that out of the key genes above only STAT3, MAPK1 and HSP90AA1 were predicted to be targeted by at least one putative bioactive compound (Supplementary Table 4). It is notable that STAT3 is only targeted by Urinatetraline, which was only found in Phyllanthus niruri. HSP90AA1 was targeted by 10-oxo methyl ester from Hibiscus-sinensis rosa, and hinokinin and hypophyllantin from Phyllantus niruri; MAPK1 was targeted by lauric acid from Hibiscus-sinensis rosa and Costus speciosus, and phyllinirurin from Phyllanthus niruri. A special note should be made about urinatetralin, a unique lignan of phenylpropanoid compound first discovered and purified from an ethanol/hexane extract of Phyllanthus urinaria root (Chang et al., 2003) and then from a methanol extract of cell suspension cultures developed from the leave callus of Phyllanthus niruri (Batterman et al., 2006). The pure compound of urinatetralin has not been purified for in vitro or in vivo testing of its pharmacological effect since then (Lee et al., 2016; Li et al., 2009), even though the crude methanolic extract from the leaves was tested to possess anti-inflammatory effects on inflammation-induced laboratory rats (Mostofa et al., 2017). In this study, urinatetralin was first predicted to be a bioactive compound that passed the ADME criteria. More importantly, it targets STAT3, which is the hub gene of the PPI network made up of all predicted targets and coronavirus-related genes. This is in agreement with Matsuyama et al. (2020), who proposed that SARS-CoV-2 mediates the dysregulation of the STAT3 signaling networks, which result in the pervasive pathological features of COVID-19 (Matsuyama et al., 2020).

However, this result should be interpreted with caution, as the currently known clinical outcomes of Covid-19 mediated by these pathways remains hypothetical and extensively debated. For instance, a special note was made on the renin-angiotensin system (RAS), which had the highest gene ratio obtained from KEGG pathway enrichment analysis (Figure 4b). The RAS has two key enzymes, ACE1 and ACE2, which control the balance of the angiotensin family. It is well-known that ACE2 is used for viral cell entry; thus it can be intuitively conceived that the greater the amount of ACE2 in the cell membrane, the greater the chance of viral entry into multiple cell types expressing ACE2, leading to ARDS and multi-organ failure in severe cases. In contrast, children who naturally have higher ACE2 as compared with elders, usually have very mild symptoms if infected (Dong et al., 2020). A hypothesis on the RAS imbalance was recently proposed (Lanza et al., 2020), trying to answer the reason why ARDS are significantly higher in elders with diabetes, hypertension and cardiovascular diseases as comorbidities. These patients are usually treated with ACE inhibitors (which block the action of ACE1) or angiotensin 
receptor blockers (ARB, which block the action of angiotensin II) of the RAS pathway, resulting in decreased ACE1 but upregulation of ACE2 (Furuhashi et al., 2015). An in vivo study showed that the Spike protein led to down-regulation of ACE2 and more severe lung injury in mice, which could be attenuated by administration of ARB (Imai et al., 2005; Kuba et al., 2005). It was hypothesized that excessive ACE2 may competitively bind with SARS-CoV-2 Spike protein and supplement cellular ACE2 activity, which negatively regulates the RAS to protect the lung from injury (Kuster et al., 2020). However, this plausible protective therapeutics against advanced stage COVID-19 remains clinically unproven until tried (Aronson and Ferner, 2020; Gurwitz, 2020). In this study, instead of ACE2, the other component genes of the RAS pathway, i.e., CMA1, CPA3, CTST, MME, PRCP and REN (Nehme et al., 2019), are predicted to be targeted by CHP bioactive compounds (Supplementary Table 4). In line with the current debated hypotheses above, this suggests that targeting the component genes could be helpful to regulate the level of ACE2 in the infected cells and be extrapolated to be protective against ARDS.

Although CHP could be effective against coronaviruses, there are a number of limitations that should be considered. First, the ethnomedicine cocktail is made up of multiple natural products in the form of a crude extract. All the currently identified compounds only represent a subset of the total compounds in all three plants. The outcome could be attributed solely or in combination with other new compounds that have not been previously identified. Second, the ethnomedicine has synonymous concept of combination therapy, i.e, the use of multiple drugs to improve clinical outcomes, but systematic highthroughput testing of its combination and dosage could not be conducted. It is used by intuition and experience gained from traditional knowledge. Third, the current findings are based upon computational prediction, but not on experimental verified drug-target interactions, as compared with drug repurposing. An intuitive and straightforward way to identify new targets for a drug is to compare the candidate proteins with those existing targets of that drug. Different results may be obtained depending from which perspective the comparison was made. Fourth, the elusive mechanism of viral infection remains to be discovered. This affects the comprehensiveness of the prediction since only a known, limited number of protein associated to host-virus interactome (inclusive of defense, regulation and other cellular pathways) were extracted from recent published studies.

\section{Materials and Methods}

\subsection{Prediction of bioactive compounds and target genes}

Costus speciosus (J.Koenig) Sm., Hibiscus rosa-sinensis L. and Phyllanthus niruri L., (abbreviated as CHP) have been verified for their name from http://www.theplantlist.org/. Known chemical constituents of CHP were extracted from three databases, which were Dr. Duke's Phytochemical and Ethnobotanical Databases (https://phytochem.nal.usda.gov/phytochem/search), Traditional Chinese Medicine Systems Pharmacology Database and Analysis Platform (TCMSP, http://www.tcmspw.com/tcmsp.php) and Bioinformatic Analysis Tool for Molecular Mechanism of Traditional Chinese Medicine (BATMAN-TCM, http://bionet.ncpsb.org/batman-tcm) (Liu et al., 2016; Ru et al., 2014; U.S. Department of Agriculture, 2016). Updated findings of each plant species were also referred (Al-Snafi, 2018; Bagalkotkar et al., 2006; El-far AH, Shaheen, HM, Alsenosy, AW, El-Sayed YS, Al Jaouni SK, Mousa, 2018; Jadhav et al., 2009; Kamruzzaman and Hoq, 2016; Kumar et al., 2018b, 2018a; Missoum, 2018; Mohamad et al., 2018; Narendra et al., 2012; Pawar and Pawar, 2014; Qiao et al., 2002; Rani et al., 2012; Salem et al., 2014; Thabit, 2018; Thambi and Shafi, 2015; Waisundara et al., 2015) and compiled into a list of compounds (Supplementary Table 1). Compounds that do not possess the canonical simplified molecular-input line-entry system (SMILES) in PubChem were removed. 
Each compound was screened to measure its oral bioavailability (OB) and druglikeness (DL) in accordance with the absorption, distribution, metabolism and excretion (ADME) properties. The OB and DL properties were calculated using SwissADME (http://www.swissadme.ch/) (Daina et al., 2017). Additional criteria were set for the compounds to be high in gastrointestinal (GI) absorption, able to cross the blood-brain barrier (BBB), and not violate both Lipinski's rule of five (Lipinski, 2004) and Veber's rule (Veber et al., 2002). Target prediction for each bioactive compound was conducted with the SwissTargetPrediction database (http://www.swisstargetprediction.ch/), depending on chemical similarities and limited to Homo sapiens and probability $>0$ to possess high confidence level of the predicted target through extracting extensive information of known experimental bioactivity (Gfeller et al., 2014). Duplicates were removed and the name of each gene was standardized in accordance with UniProt database (http://www.uniprot.org/).

\subsection{Construction of compound-target network}

The putative bioactive compounds and predicted target genes retrieved from the databases were inputted into Cytoscape version 3.8 (Shannon et al., 2003) to construct the compound-target network for better visualization. The pharmacology of CHP was characterized using the multi-compound and multi-target network. In addition, the unique and shared target genes of each individual plant was analyzed and visualized with a Venn diagram.

\subsection{Acquisition of coronavirus-related genes}

Coronavirus-related genes that are known to be associated with coronavirus diseases were searched and screened to identify biological attributes relevant to the pathogenesis of coronavirus viral infections. The coronaviruses included in the analyses were alphacoronavirus, betacoronavirus, gammacoronavirus, severe acute respiratory syndrome-related (SARS) coronavirus, Middle East respiratory syndrome-related (MERS) coronavirus, and severe acute respiratory syndrome coronavirus 2 (SARS-CoV-2) according to the search keywords shown in Supplementary Table 3. Two databases, Online Mendelian Inheritance in Man (OMIM, https://omim.org/) and National Center for Biotechnology Information (NCBI, https://www.ncbi.nlm.nih.gov/gene?cmd=Retrieve) (Agarwala et al., 2016; Amberger et al., 2019) were used to search for coronavirus-related genes using these keywords.

\subsection{Identification of hub and key target genes via protein-protein interaction network}

All compound-target and coronavirus-related genes were compiled and duplicates were removed. This compiled set of genes was inputted into STRING 11.0 (https://stringdb.org/) database (Szklarczyk et al., 2019) to obtain the interactions information among the proteins. A confidence score of 0.98 was selected for the highest confidence of the interaction and clustered with an inflation value of 1.8 using Markov Clustering (MCL) before it was imported to Cytoscape Version 3.8 (Shannon et al., 2003) to visualize the graphical network. MCL clustering was used to group highly interconnected nodes, revealing interplay between myriad pathways. The value of 'degree', which is the number of links to each node (protein) was referred. The application 'NetworkAnalyzer' was then used to calculate the node 'degree' and 'betweenness centrality' (BC), which serve as the key topological parameters for the PPI network. Key genes were identified from the hub and bottleneck nodes with high node degree and $B C$ value.

\subsection{Identification of hub and key target genes via protein-protein interaction network}

To investigate the pharmacological potential of CHP bioactive compounds, the underlying mechanism of action on biological pathways of the candidate targets were referred. Gene ontology (GO) and Kyoto Encyclopedia of Genes and Genomes (KEGG) 
pathway enrichment analysis were performed by STRING 11.0 (Kanehisa et al., 2019; Szklarczyk et al., 2019; The Gene Ontology Consortium, 2019). Only statistically significant ( $\mathrm{p}$-value $<0.05$ ) biological process or pathways were subsequently analyzed with $\mathrm{R}$ version 3.6.3 (RStudio Team, 2020).

\section{Conclusions}

Analyses of network pharmacology of CHP ethnomedicine showed that its bioactive compounds should have plausible synergy in regulating inflammation via STAT3-mediated pathways, upon infection of human subjects by coronaviruses. In this study, urinatetralin was predicted, for the first time, to be a bioactive compound that passes the ADME criteria. More importantly, it targets STAT3, which is the hub gene of the PPI network made up of all predicted targets and coronavirus-related genes. Because STAT3 is wellknown for its versatility in mediating inflammation and viral infection, further analyses and evidence-based experiments should be conducted.

Supplementary Materials: Figure S1: title, Table S1: Oral Bioavailability and drug likeness of listed compounds for CHP, Table S2: Network properties of target gene, Table S3: Search keywords for coronaviruses targets in OMIM and NCBI databases, Table S4: List of genes targeted by compounds in $\mathrm{CHP}$.

Author Contributions: Conceptualization, methodology and funding acquisition F.F.L. and F.T.C.; Formal analysis and design of the study, F.F.L., K.M.L. and S.N.C.; Resources, D.J.H.L.; writingoriginal draft preparation, F.F.L. and C.W.Y.; writing-review and editing, F.F.L. and F.T.C..; All authors have read and agreed to the published version of the manuscript.

Funding: Not applicable.

Institutional Review Board Statement: Ethical clearance is exempted, as approved by the Medical Research and Ethics Committee (MREC), Ministry of Health Malaysia (NMRR-20-1729-56018), because no personal information or samples from human subjects are used in this research study.

Informed Consent Statement: Not applicable.

Data Availability Statement: The data analyzed in this study is subject to the following licenses/restrictions: No restrictions. Requests to access these datasets should be directed to FFL, lemfuifui@moh.gov.my.

Acknowledgments: The authors would like to express their sincere thanks to the Director General of Health Malaysia for granting permission to publish this article.

Conflicts of Interest: The authors declare no conflict of interest.

\section{References}

Agarwala, R., Barrett, T., Beck, J., Benson, D.A., Bollin, C., Bolton, E., Bourexis, D., Brister, J.R., Bryant, S.H., Canese, K., Charowhas, C., Clark, K., Dicuccio, M., Dondoshansky, I., Federhen, S., Feolo, M., Funk, K., Geer, L.Y., Gorelenkov, V., Hoeppner, M., Holmes, B., Johnson, M., Khotomlianski, V., Kimchi, A., Kimelman, M., Kitts, P., Klimke, W., Krasnov, S., Kuznetsov, A., Landrum, M.J., Landsman, D., Lee, J.M., Lipman, D.J., Lu, Z., Madden, T.L., Madej, T., Marchler-Bauer, A., Karsch-Mizrachi, I., Murphy, T., Orris, R., Ostell, J., O'sullivan, C., Panchenko, A., Phan, L., Preuss, D., Pruitt, K.D., Rodarmer, K., Rubinstein, W., Sayers, E., Schneider, V., Schuler, G.D., Sherry, S.T., Sirotkin, K., Siyan, K., Slotta, D., Soboleva, A., Soussov, V., Starchenko, G., Tatusova, T.A., Todorov, K., Trawick, B.W., Vakatov, D., Wang, Y., Ward, M., Wilbur, W.J., Yaschenko, E., Zbicz, K., 2016. Database resources of the National Center for Biotechnology Information. Nucleic Acids Res. 44, D7-D19. https://doi.org/10.1093/nar/gkv1290

Ahmad, F.B., Holdsworth, D.K., 2003. Medicinal plants of Sabah, East Malaysia - Part I. Pharm. Biol. 41, $340-346$. https://doi.org/10.1076/phbi.41.5.340.15940

Ahmad, F.B., Holdsworth, D.K., L, A.V., 1994. Medicinal Plants of Sabah, Malaysia , Part 11 . The Muruts The Murut people of 
Borneo island are found in the northeast of Sarawak and the um , Kota Kinabalu and voucher specimens are kept at this Herbarium, as listed 32, 378-383.

Al-Snafi, A.E., 2018. Chemical constituents, pharmacological effects and therapeutic importance of Hibiscus rosa-sinensis- A review. Int. J. Pharm. Res. 8, 101-119.

Álvarez, Á.L., Dalton, K.P., Nicieza, I., Diñeiro, Y., Picinelli, A., Melón, S., Roque, A., Suárez, B., Parra, F., 2012. Bioactivity-guided fractionation of phyllanthus orbicularis and identification of the principal anti HSV-2 compounds. Phyther. Res. 26, $1513-1520$. https://doi.org/10.1002/ptr.4608

Amberger, J.S., Bocchini, C.A., Scott, A.F., Hamosh, A., 2019. OMIM.org: Leveraging knowledge across phenotype-gene relationships. Nucleic Acids Res. 47, D1038-D1043. https://doi.org/10.1093/nar/gky1151

Aronson, J.K., Ferner, R.E., 2020. Drugs and the renin-angiotensin system in covid-19 Clinical effects are unpredictable , so treatment decisions must be tailored and pragmatic. BMJ 369, m1313. https://doi.org/10.1136/bmj.m1313

Bagalkotkar, G., Sagineedu, S., Saad, M., Stanslas, J., 2006. Phytochemicals from Phyllanthus niruri Linn. and their pharmacological properties: a review. J. Pharm. Pharmacol. 58, 1559-1570. https://doi.org/10.1211/jpp.58.12.0001

Barabási, A., Gulbahce, N., Loscalzo, J., 2011. Network medicine : a network-based approach to human disease. Nat. Rev. Genet. 12, 56-68. https://doi.org/10.1038/nrg2918

Batterman, S., Koulman, A., Hackl, T., Bos, R., Kayser, O., Herman, J., Quax, W.J., 2006. Lignans from cell suspension cultures of Phyllanthus niruri, an Indonesian medicinal plant. J. Nat. Prod. 69, 55-58. https://doi.org/10.1021/np050288b

Cao, B., Wang, Y., Wen, D., Liu, W., Wang, Jingli, Fan, G., Ruan, L., Song, B., Cai, Y., Wei, M., Li, X., Xia, J., Chen, N., Xiang, J., Yu, T., Bai, T., Xie, X., Zhang, L., Li, C., Yuan, Y., Chen, H., Li, Huadong, Huang, H., Tu, S., Gong, F., Liu, Y., Wei, Y., Dong, C., Zhou, F., Gu, X., Xu, J., Liu, Z., Zhang, Y., Li, Hui, Shang, L., Wang, K., Li, K., Zhou, X., Dong, X., Qu, Z., Lu, S., Hu, X., Ruan, S., Luo, S., Wu, J., Peng, L., Cheng, F., Pan, L., Zou, J., Jia, C., Wang, Juan, Liu, X., Wang, S., Wu, X., Ge, Q., He, J., Zhan, H., Qiu, F., Guo, L., Huang, C., Jaki, T., Hayden, F.G., Horby, P.W., Zhang, D., Wang, C., 2020. A Trial of Lopinavir-Ritonavir in Adults Hospitalized with Severe Covid-19. NEJM 382, 1787-1799. https://doi.org/10.1056/NEJMoa2001282

Chang, C., Lien, Y., Liu, K.C.S.C., Lee, S., 2003. Lignans from Phyllanthus urinaria. Phytochemistry 63, 825-833. https://doi.org/10.1016/S0031-9422(03)00371-6

Chang, Z., Wang, Y., Zhou, X., Long, J., 2018. STAT3 roles in viral infection : antiviral or proviral ? 13, 557-574.

Charitou, T., Bryan, K., Lynn, D.J., 2016. Using biological networks to integrate, visualize and analyze genomics data. Genet. Sel. Evol. 48, 1-12. https://doi.org/10.1186/s12711-016-0205-1

Chassey, B. De, Meyniel-schicklin, L., Vonderscher, J., André, P., Lotteau, V., 2014. Virus-host interactomics : new insights and opportunities for antiviral drug discovery Influenza virus. Genome Med. 2014, 6, 115. https://doi.org/10.1186/s13073-014-0115-1

Choy, E., Rose-John, S., 2017. Interleukin-6 as a multifunctional regulator: inflammation, immune response, and fibrosis. J. Scleroderma Relat. Disord. 2, S1-5. https://doi.org/10.5301/jsrd.5000265

Colson, P., Rolain, J.M., Lagier, J.C., Brouqui, P., Raoult, D., 2020. Chloroquine and hydroxychloroquine as available weapons to fight COVID-19. Int. J. Antimicrob. Agents 55, 105932. https://doi.org/10.1016/j.ijantimicag.2020.105932

Coperchini, F., Chiovato, L., Croce, L., Magri, F., Rotondi, M., 2020. The cytokine storm in COVID-19: An overview of the involvement of the chemokine/chemokine-receptor system. Cytokine Growth Factor Rev. 53, 25-32. https://doi.org/10.1016/j.cytogfr.2020.05.003

Daina, A., Michielin, O., Zoete, V., 2017. SwissADME: A free web tool to evaluate pharmacokinetics, drug-likeness and medicinal chemistry friendliness of small molecules. Sci. Rep. 7, 1-13. https://doi.org/10.1038/srep42717

Dong, Y., Mo, X., Hu, Y., Qi, X., Jiang, F., Jiang, Z., 2020. Epidemiology of COVID-19 Among Children in China. Pediatrics 145, e20200702. https://doi.org/10.1542/peds.2020-0702

El-far AH, Shaheen, HM, Alsenosy, AW, El-Sayed YS, Al Jaouni SK, Mousa, S., 2018. Costus speciosus: Traditional Uses, 
Phytochemistry, and Therapeutic Potentials. Pharmacogn. Rev. 12, 120-127. https://doi.org/10.4103/phrev.phrev El-kafrawy, S.A., Corman, V.M., Tolah, A.M., Masaudi, S.B. Al, Hassan, A.M., Müller, M.A., Bleicker, T., Harakeh, S.M., Alzahrani, A.A., Alsaaidi, G.A., Alagili, A.N., Hashem, A.M., Zumla, A., Drosten, C., Azhar, E.I., 2019. Enzootic patterns of Middle East respiratory syndrome coronavirus in imported African and local Arabian dromedary camels : a prospective genomic study. Lancet Planet Heal. 3, e521-528. https://doi.org/10.1016/S2542-5196(19)30243-8

Fang, J., Liu, C., Wang, Q., Lin, P., Cheng, F., 2018. In silico polypharmacology of natural products. Brief. Bioinform. 19, $1153-1171$. https://doi.org/10.1093/bib/bbx045

Fielding, C.A., Mcloughlin, R.M., Mcleod, L., Colmont, C.S., Najdovska, M., Grail, D., Jones, S.A., Topley, N., Brendan, J., Stat, I., Fielding, C.A., Mcloughlin, R.M., Mcleod, L., Colmont, C.S., Najdovska, M., Grail, D., Ernst, M., Jones, S.A., Topley, N., Jenkins, B.J., 2008. IL-6 Regulates Neutrophil Trafficking during Acute Inflammation via STAT3. J. Immunol. 181, $2189-2195$. https://doi.org/10.4049/jimmunol.181.3.2189

Forero, J.J.E., Avila, L., Taborda, N., Tabares, P., Lopez, A., Torres, F., Quinones, W., Bucio, M.A., Mora-Perez, Y., Rugeles, M.M.T., Nathan, P., Echeverri, F., López, A., Torres, F., Quiñones, W., Bucio, M.A., Mora-Pérez, Y., Rugeles, M.M.T., Joseph-Nathan, P., Echeverri, F., 2008. In vitro anti-influenza screening of several Euphorbiaceae species: Structure of a bioactive Cyanoglucoside from Codiaeum variegatum. Phytochemistry 69, 2815-2819. https://doi.org/10.1016/j.phytochem.2008.09.003

Furuhashi, M., Moniwa, N., Mita, T., Fuseya, T., Ishimura, S., Ohno, K., Shibata, S., Tanaka, M., Watanabe, Y., Akasaka, H., Ohnishi, H., Yoshida, H., Takizawa, H., Saitoh, S., Ura, N., Shimamoto, K., Miura, T., 2015. Urinary Angiotensin-Converting Enzyme 2 in Hypertensive Patients May Be Increased by Olmesartan , an Angiotensin II Receptor Blocker. Am. J. Hypertens. 28 , 15-21. https://doi.org/10.1093/ajh/hpu086

Gfeller, D., Grosdidier, A., Wirth, M., Daina, A., Michielin, O., Zoete, V., 2014. SwissTargetPrediction: A web server for target prediction of bioactive small molecules. Nucleic Acids Res. 42, 32-38. https://doi.org/10.1093/nar/gku293

Gordon, C.J., Tchesnokov, E.P., Feng, J.Y., Porter, D.P., Götte, M., 2020. The antiviral compound remdesivir potently inhibits RNAdependent RNA polymerase from Middle East respiratory syndrome coronavirus. J. Biol. Chem. 295, $4773-4779$. https://doi.org/10.1074/jbc.AC120.013056

Gordon, D.E., Hiatt, J., Bouhaddou, M., Rezelj, V. V, Ulferts, S., Braberg, H., Jureka, A.S., Obernier, K., Guo, J.Z., Batra, J., Kaake, R.M., Weckstein, A.R., Owens, T.W., Gupta, M., Pourmal, S., Titus, E.W., Cakir, M., 2020a. Comparative host-coronavirus protein interaction networks reveal pan-viral disease mechanisms Comparative host-coronavirus protein interaction networks reveal pan-viral disease mechanisms. Science (80-. ). 370, 1181. https://doi.org/10.1126/science.abe9403

Gordon, D.E., Jang, G.M., Bouhaddou, M., Xu, J., Obernier, K., White, K.M., O’Meara, M.J., Rezelj, V. V, Guo, J.Z., Swaney, D.L., Tummino, T.A., Huttenhain, R., Kaake, R.M., Richards, A.L., Tutuncuoglu, B., Foussard, H., Batra, J., Haas, K., Modak, M., Kim, M., Haas, P., Polacco, B.J., Braberg, H., Fabius, J.M., Eckhardt, M., Soucheray, M., Bennet, M.J., Cakir, M., McGregor, M.J., Li, Q., Meyer, B., Roesch, F., Vallet, T., Kain, A.M., Miorin, L., Moreno, E., Naing, Z.Z., Zhou, Y., Peng, S., Shi, Y., Zhang, Z., Shen, W., Kirby, I.T., Melnyk, J.E., Chorba, J.S., Lou, K., Dai, S.A., Hernandez, I.B., Memon, D., 2020b. A SARS-CoV-2 protein interaction map reveals targets for drug repurposing. Nature 583, 459-468. https://doi.org/10.1038/s41586-020-2286-9

Gurwitz, D., 2020. Angiotensin receptor blockers as tentative SARS-CoV-2 therapeutics. Drug Dev. Res. 81, 537-540. https://doi.org/10.1002/ddr.21656

Hu, B., Guo, H., Zhou, P., Shi, Z.-L., 2021. Characteristics of SARS-CoV-2 and COVID-19. Nat. Rev. Microbiol. 19, 141-154. https://doi.org/10.1038/s41579-020-00459-7

Hu, Y.S., Han, X., Liu, X.H., 2019. STAT3 : A Potential Drug Target for Tumor and Inflammation. Curr. Top. Med. Chem. $19,1-13$. https://doi.org/10.2174/1568026619666190620145052

Huang, C., Wang, Y., Li, X., Ren, L., Zhao, J., Hu, Y., Zhang, L., Fan, G., Xu, J., Gu, X., Cheng, Z., Yu, T., Xia, J., Wei, Y., Wu, W., Xie, X., Yin, W., Li, H., Liu, M., Xiao, Y., Gao, H., Huo, L., Xie, J., Wang, G., Jiang, R., Gao, Z., Qi, J., Wang, J., Cao, B., 2020. Clinical 
features of patients infected with 2019 novel coronavirus in Wuhan, China. Lancet 395, 497-506. https://doi.org/10.1016/S01406736(20)30183-5

IH, B., 1966. A Dictionary of the Economic Products of the Malay Peninsula. Nature. https://doi.org/10.1038/137255c0

Imai, Y., Kuba, K., Rao, S., Huan, Y., Guo, F., Guan, B., Yang, P., Sarao, R., Wada, T., Leong-poi, H., Crackower, M.A., Fukamizu, A., Hui, C., Hein, L., Uhlig, S., Slutsky, A.S., Jiang, C., Penninger, J.M., 2005. Angiotensin-converting enzyme 2 protects from severe acute lung failure. Nature 436, 112-116. https://doi.org/10.1038/nature03712

Institute Medical Research, M.N.I. of H., 2018. GlobinMed [WWW Document]. URL https://www.globinmed.com/index.php?option=com_content\&view $=$ article\&id=80849\&Itemid $=101$

Jadhav, V., Thorat, R., Kadam, V., Sathe, N., 2009. Hibiscus rosa sinensis Linn - ““ Rudrapuspa "' : A Review. J. Pharm. Res. 2, 11681173.

Kamruzzaman, H.M., Hoq, M.O., 2016. A review on ethnomedicinal, phytochemical and pharmacological properties of Phyllanthus niruri. J. Med. Plants Stud. 4, 173-180.

Kanehisa, M., Sato, Y., Furumichi, M., Morishima, K., Tanabe, M., 2019. New approach for understanding genome variations in KEGG. Nucleic Acids Res. 47, D590-D595. https://doi.org/10.1093/nar/gky962

Kim, J., Choi, H., Kim, S., Lee, D., 2019. The PAK1-Stat3 Signaling Pathway Activates IL-6 Gene Transcription and Human Breast Cancer Stem Cell Formation. MDPI Cancers 11, 1527. https://doi.org/10.3390/cancers11101527

Ko, W., Rolain, J., Lee, N., Chen, P., Huang, C., Lee, P.I., Hsueh, P.R., 2020. Arguments in favour of remdesivir for treating SARSCoV-2 infections. Int. J. Antimicrob. Agents 55, 105933. https://doi.org/10.1016/j.ijantimicag.2020.105933

Kodoh, J., Mojiol, A.R., Lintangah, W., Gisiu, F., Maid, M., Kang Chiang, L., 2017. Traditional knowledge on the uses of medicinal plants among the ethnic communities in kudat, sabah, malaysia. Int. J. Agric. For. Plant. 5, 79-85.

Kuba, K., Imai, Y., Rao, S., Gao, H., Guo, F., Guan, B., Huan, Y., Yang, P., Zhang, Y., Deng, W., Bao, L., Zhang, B., Liu, G., Wang, Z., Chappell, M., Liu, Y., Zheng, D., Leibbrandt, A., Wada, T., Slutsky, A.S., Liu, D., Qin, C., Jiang, C., Penninger, J.M., 2005. A crucial role of angiotensin converting enzyme 2 ( ACE2 ) in SARS coronavirus - induced lung injury. Nat. Med. 11, 875-879. https://doi.org/10.1038/nm1267

Kumar, A., Chand, G., Agnihotri, V.K., 2018a. A new oxo-sterol derivative from the rhizomes of Costus speciosus. Nat. Prod. Res. 32, 18-22. https://doi.org/10.1080/14786419.2017.1324962

Kumar, A., Maurya, A.K., Chand, G., Agnihotri, V.K., 2018b. Comparative metabolic profiling of Costus speciosus leaves and rhizomes using NMR, GC-MS and UPLC/ESI-MS/MS. Nat. Prod. Res. 32, 826-833. https://doi.org/10.1080/14786419.2017.1365069

Kuster, G.M., Pfister, O., Burkard, T., Zhou, Q., Twerenbold, R., Haaf, P., Widmer, A.F., Osswald, S., 2020. SARS-CoV2 : should inhibitors of the renin - angiotensin system be withdrawn in patients with COVID-19? Eur. Heart J. 41, $1801-1803$. https://doi.org/10.1093/eurheartj/ehaa235

Lanza, K., Perez, L.G., Costa, L.B., Cordeiro, T.M., Palmeira, V.A., Ribeiro, V.T., Cristina, A., 2020. Covid-19: the renin - angiotensin system imbalance hypothesis. Clin. Sci. 134, 1259-1264. https://doi.org/10.1042/CS20200492

Lee, N.Y.S., Khoo, W.K.S., Adnan, M.A., Mahalingam, P.T., Fernandez, A.R., Jeevaratnam, K., 2016. The pharmacological potential of Phyllanthus niruri. J. Pharm. Pharmacol. 68, 953-969. https://doi.org/10.1111/jphp.12565

Lem, F.F., Opook, F., Lee, D.J.H., Chee, F.T., Lawson, F.P., Chin, S.N., 2021. Molecular Mechanism of Action of Repurposed Drugs and Traditional Chinese Medicine Used for the Treatment of Patients Infected With COVID-19: A Systematic Scoping Review. Front. Pharmacol. 11, 1-15. https://doi.org/10.3389/fphar.2020.585331

Li, L., Lu, F.G., He, Q.H., 2009. Efficacy of Maxing Shigan Decoction combined with Western medicine for pneumonia in children: A systematic review and meta-analysis. J. Chinese Integr. Med. https://doi.org/10.3736/jcim20090902

Lipinski, C.A., 2004. Lead- and drug-like compounds: The rule-of-five revolution. Drug Discov. Today Technol. 1, $337-341$. https://doi.org/10.1016/j.ddtec.2004.11.007 
Liu, Z., Guo, F., Wang, Y., Li, C., Zhang, X., Li, H., Diao, L., Gu, J., Wang, W., Li, D., He, F., 2016. BATMAN-TCM: a Bioinformatics Analysis Tool for Molecular mechANism of Traditional Chinese Medicine. Sci. Rep. 6, 21146. https://doi.org/10.1007/BF01053362

Lu, R., Zhao, X., Li, J., Niu, P., Yang, B., Wu, H., Wang, W., Song, H., Huang, B., Zhu, N., Bi, Y., Ma, X., Zhan, F., Wang, L., Hu, T., Zhou, H., Hu, Z., Zhou, W., Zhao, L., Chen, J., Meng, Y., Wang, J., Lin, Y., Yuan, J., Xie, Z., Ma, J., Liu, W.J., Wang, D., Xu, W., Holmes, E.C., Gao, G.F., Wu, G., Chen, W., Shi, W., Tan, W., 2020. Genomic characterisation and epidemiology of 2019 novel coronavirus: implications for virus origins and receptor binding. Lancet 395, 565-574. https://doi.org/10.1016/S01406736(20)30251-8

Lukassen, S., Chua, R.L., Trefzer, T., Kahn, N.C., Schneider, M.A., Muley, T., Winter, H., Meister, M., Veith, C., Boots, A.W., Hennig, B.P., Kreuter, M., Conrad, C., Eils, R., 2020. SARS-CoV- 2 receptor ACE 2 and TMPRSS 2 are primarily expressed in bronchial transient secretory cells. EMBO J. 39, e105114. https://doi.org/10.15252/embj.20105114

Matsuyama, T., Kubli, S.P., Yoshinaga, S.K., Pfeffer, K., 2020. An aberrant STAT pathway is central to COVID-19. Cell Death Differ. 27, 3209-3225. https://doi.org/10.1038/s41418-020-00633-7

Missoum, A., 2018. An update review on Hibiscus rosa sinensis phytochemistry and medicinal uses. J. Ayurvedic Herb. Med. 4, 135146.

Mizutani, T., Fukushi, S., Murakami, M., Hirano, T., Saijo, M., 2004. Tyrosine dephosphorylation of STAT3 in SARS coronavirusinfected Vero E6 cells. FEBS Lett. 577, 187-192. https://doi.org/10.1016/j.febslet.2004.10.005

Mohamad, S., Ismail, N.N., Parumasivam, T., Ibrahim, P., Osman, H., A. Wahab, H., 2018. Antituberculosis activity, phytochemical identification of Costus speciosus (J. Koenig) Sm., Cymbopogon citratus (DC. Ex Nees) Stapf., and Tabernaemontana coronaria (L.) Willd. and their effects on the growth kinetics and cellular integrity of Mycobacteri. BMC Complement. Altern. Med. 18, 1-14. https://doi.org/10.1186/s12906-017-2077-5

Mostofa, R., Ahmed, S., Begum, M.M., Rahman, S., Begum, T., Ahmed, S.U., Tuhin, R.H., Das, M., Hossain, A., Sharma, M., Begum, R., 2017. Evaluation of anti-inflammatory and gastric anti-ulcer activity of Phyllanthus niruri L . ( Euphorbiaceae ) leaves in experimental rats. BMC Complement. Altern. Med. 17, 267. https://doi.org/10.1186/s12906-017-1771-7

Naik, A.D., Juvekar, A.R., 2003. Effects of alkaloidal extract of Phyllanthus niruri on HIV replication. Indian J. Med. Sci. 57, 387-393.

Narendra, K., Swathi, J., Sowjanya, K., Satya, K.A., 2012. Phyllanthus niruri: a review on its ethno botanical, phytochemical and pharmacological profile. J. Pharm. Res. 5, 4681-4691.

Nehme, A., Zouein, F.A., Zayeri, Z.D., Zibara, K., 2019. An Update on the Tissue Renin Angiotensin System and Its Role in Physiology and Pathology. J. Cardiovasc. Dev. Dis. 6, 14. https://doi.org/10.3390/jcdd6020014

Nguyen, P.Q.T., Ooi, J.S.G., Nguyen, N.T.K., Wang, S., Huang, M., Liu, D.X., Tam, J.P., 2015. Antiviral cystine knot $\alpha$-amylase inhibitors from alstonia scholaris. J. Biol. Chem. 290, 31138-31150. https://doi.org/10.1074/jbc.M115.654855

Niu, S., Tian, S., Lou, J., Kang, X., Zhang, L., Lian, H., Zhang, J., 2020. Clinical characteristics of older patients infected with COVID19: A descriptive study. Arch. Gerontol. Geriatr. 89, 104058. https://doi.org/10.1016/j.archger.2020.104058

Orhan, I.E., 2012. Biotechnological Production of plant Secondary Metabolites. Biotechnol. Prod. Plant Second. Metab. https://doi.org/10.2174/97816080511441120101

Palmieri, L., Vanacore, N., Donfrancesco, C., Lo Noce, C., Canevelli, M., Punzo, O., Raparelli, V., Pezzotti, P., Riccardo, F., Bella, A., Fabiani, M., D’Ancona, F.P., Vaianella, L., Tiple, D., Colaizzo, E., Palmer, K., Rezza, G., Piccioli, A., Brusaferro, S., Onder, G., Group, I.N.I. of H.C.-19 mortality, 2020. Clinical Characteristics of Hospitalized Individuals Dying with COVID-19 by Age Group in Italy. Journals Gerontol. Ser. A 75, 1796-1800.

Pawar, V., Pawar, P., 2014. Costus speciosus: An Important Medicinal Plant. Int. J. Sci. Res. 3, $28-33$.

Qiao, C.F., Li, Q.W., Dong, H., Xu, L.S., Wang, Z.T., 2002. Studies on chemical constituents of two plants from Costus. Zhongguo Zhongyao Zazhi 27, 123-125. 
Rani, A.S., Sulakshana, G., Patnaik, S., 2012. Costus speciosus, an antidiabetic plant-review. FS J Pharma Res 1, 52-53.

RStudio Team, 2020. RStudio:Integrated Development for R.

Ru, J., Li, Peng, Wang, J., Zhou, W., Li, B., Huang, C., Li, Pidong, Guo, Z., Tao, W., Yang, Y., Xu, X., Li, Y., Wang, Y., Yang, L., 2014. TCMSP: a database of systems pharmacology for drug discovery from herbal medicines. J. Cheminform. 6, 13.

Salem, M.Z., Olivares-Perez, J., Salem, A., 2014. Studies on biological activities and phytochemicals composition of Hibiscus speciesA review. Life Sci. J. 11, 1-8.

Saraf, A., 2010. Phytochemical and antimicrobial studies of medicinal plant costus speciosus (Koen.). E-Journal Chem. 7, $405-413$. https://doi.org/10.1155/2010/605735

Shamir, I., Haya, M.A., Paret, C.G., Nevo-caspi, Y., 2020. STAT3 isoforms differentially affect ACE2 expression : A potential target for COVID-19 therapy. J. Cell. Mol. Med. 24, 12864-12868. https://doi.org/10.1111/jcmm.15838

Shannon, P., Markiel, A., Ozier, O., Baliga, N.S., Wang, J.T., Ramage, D., Amin, N., Schwikowski, B., Ideker, T., 2003. Cytoscape: A Software Environment for Integrated Models of Biomolecular Interaction Networks. Genome Res. 13, $2498-2504$. https://doi.org/10.1101/gr.1239303.metabolite

Silva, K.M.D., Serling-, N., Wallwork, R., Hsu, T., Fu, X., Gravallese, E.M., Choi, H.K., Sparks, J.A., Wallace, Z.S., 2020. Clinical characteristics and outcomes of patients with coronavirus disease 2019 ( COVID-19) and rheumatic disease : a comparative cohort study from a US ' hot spot.' Ann. Rheum. Dis. 79, 1156-1162. https://doi.org/10.1136/annrheumdis-2020-217888

Suarez, A.A., Renne, N. V, Baumert, T.F., Lupberger, J., 2018. Viral manipulation of STAT3 : Evade , exploit, and injure. PLoS Pathog. 14, e1006839. https://doi.org/10.1371/journal. ppat.1006839

Szklarczyk, D., Gable, A.L., Lyon, D., Junge, A., Wyder, S., Huerta-Cepas, J., Simonovic, M., Doncheva, N.T., Morris, J.H., Bork, P., Jensen, L.J., Von Mering, C., 2019. STRING v11: Protein-protein association networks with increased coverage, supporting functional discovery in genome-wide experimental datasets. Nucleic Acids Res. 47, D607-D613. https://doi.org/10.1093/nar/gky1131

Thabit, Z.A., 2018. Evaluation of some bioactive effect of phenolic compounds in Costus speciosus rhizome extract. Iraqi J. Sci. 59, 38-43. https://doi.org/10.24996/ijs.2018.59.1a.6

Thambi, M., Shafi, M.P., 2015. Rhizome Essential Oil Composition of Costus Speciosus and its Antimicrobial Properties. Int. J. Pharm. Res. Allied Sci. 4, 28-32.

The Gene Ontology Consortium, 2019. The Gene Ontology Resource: 20 years and still GOing strong. Nucleic Acids Res. 47, D330D338. https://doi.org/10.1093/nar/gky1055

Tian, J., Yan, S., Wang, H., Zhang, Y., Zheng, Y., Wu, H., Li, X., Gao, Z., Ai, Y., Gou, X., Zhang, L., He, L., Lian, F., Liu, B., Tong, X., 2020. Hanshiyi Formula, a medicine for Sars-CoV2 infection in China, reduced the proportion of mild and moderate COVID19 patients turning to severe status: A cohort study. Pharmacol. Res. J. 161, 105127. https://doi.org/10.1016/j.phrs.2020.105127

U.S. Department of Agriculture, 2016. Dr. Duke's Phytochemical and Ethnobotanical Databases [WWW Document]. https://doi.org/http://dx.doi.org/10.15482/USDA.ADC/1239279

Veber, D.F., Johnson, S.R., Cheng, H.Y., Smith, B.R., Ward, K.W., Kopple, K.D., 2002. Molecular Properties That Influence the Oral Bioavailability of Drug Candidates. J. Med. Chem. 45, 2615-2623. https://doi.org/10.1021/jm020017n

Venkateswaran, P.S., Millman, I., Blumberg, B.S., 1987. Effects of an extract from Phyllanthus niruri on hepatitis B and woodchuck hepatitis viruses: In vitro and in vivo studies. Proc. Natl. Acad. Sci. U. S. A. 84, 274-278. https://doi.org/10.1073/pnas.84.1.274

Wahyuni, T.S., Azmi, D., Permanasari, A.A., Adianti, M., Tumewu, L., Widiandani, T., Utsubo, C.A., Widyawaruyanti, A., Fuad, A., Hotta, H., 2019. Anti-viral activity of Phyllanthus niruri against hepatitis C virus. Malaysian Appl. Biol. 48, $105-111$.

Waisundara, V., Watawana, M., Jayawardena, N., 2015. Costus speciosus and Coccinia grandis: Traditional medicinal remedies for diabetes. South African J. Bot. 98, 1-5. https://doi.org/10.1016/j.sajb.2015.01.012

Wang, D., Hu, B., Hu, C., Zhu, F., Liu, X., Zhang, J., Wang, B., Xiang, H., Cheng, Z., Xiong, Y., Zhao, Y., Li, Y., Wang, X., Peng, Z., 
2020. Clinical Characteristics of 138 Hospitalized Patients With 2019 Novel Coronavirus-Infected Pneumonia in Wuhan, China. JAMA - J. Am. Med. Assoc. 323, 1061-1069. https://doi.org/10.1001/jama.2020.1585

Wang, M., Yan, M., Xu, H., Liang, W., Kan, B., Zheng, B., Chen, H., Zheng, H., Xu, Y., Zhang, E., Wang, H., Ye, J., Li, G., Li, M., Cui, Z., Liu, Y., Guo, R., Liu, X., Zhan, L., Zhou, D. hua, Zhao, A., Hai, R., Yu, D., Guan, Y., Xu, J., 2005. SARS-CoV Infection in a Restaurant from Palm Civet. 1860 Emerg. Infect. Dis. 11, 1860-1865. https://doi.org/10.3201/eid1112.041293

Xiang, J.Z., Cao, D.Y., Yang, Y.Y.Y., Cezmi, Y.Y., Gao, A.A.Y., 2020. Clinical characteristics of 140 patients infected with SARS- CoV2 in Wuhan, China. Allergy 75, 1730-1741. https://doi.org/10.1111/all.14238

Xiang, Y.F., Pei, Y., Wang, Y. fei, 2008. Current status of natural products from plants as anti-herpes simplex virus 1 agents. Virol. Sin. 23, 305-314. https://doi.org/10.1007/s12250-008-2962-7

Xin, S., Cheng, X., Zhu, B., Liao, X., Yang, F., Song, L., Shi, Y., Guan, X., Su, R., Wang, J., Xing, L., Xu, X., Jin, L., Liu, Y., Zhou, W., Zhang, D., Liang, L., Yu, Y., Yu, R., 2020. Clinical retrospective study on the efficacy of Qingfei Paidu decoction combined with Western medicine for COVID-19 treatment. Biomed. Pharmacother. 129, 110500. https://doi.org/10.1016/j.biopha.2020.110500

Xu, X., Chen, P., Wang, J., Feng, J., Zhou, H., Li, X., Zhong, W., Hao, P., 2020. Evolution of the novel coronavirus from the ongoing Wuhan outbreak and modeling of its spike protein for risk of human transmission. Sci. China Life Sci. 63, 457-460. https://doi.org/10.1007/s11427-020-1637-5

Xu, Z., Shi, L., Wang, Y., Zhang, J., Huang, L., Zhang, C., Liu, S., Zhao, P., Liu, H., Zhu, L., Tai, Y., Bai, C., Gao, T., Song, J., Xia, P., Dong, J., Zhao, J., Wang, F., 2020. Pathological findings of COVID-19 associated with acute respiratory distress syndrome. Lancet Respir. 8, 420-422. https://doi.org/10.1016/S2213-2600(20)30076-X

Yang, R., Liu, H., Bai, C., Wang, Yingchao, Zhang, X., Guo, R., Wu, S., Wang, J., Leung, E., Chang, H., Li, P., Liu, T., Wang, Yi, 2020. Chemical composition and pharmacological mechanism of Qingfei Paidu Decoction and Ma Xing Shi Gan Decoction against Coronavirus Disease 2019 (COVID-19): In silico and experimental study. Pharmacol. Res. J. 157, 104820. https://doi.org/10.1016/j.phrs.2020.104820

Yang, X., Yu, Y., Xu, J., Shu, H., Xia, J., Liu, H., Wu, Y., Zhang, L., Yu, Z., Fang, M., Yu, T., Wang, Y., Pan, S., Zou, X., Yuan, S., Shang, Y., 2020. Clinical course and outcomes of critically ill patients with SARS-CoV-2 pneumonia in Wuhan, China: a single-centered, retrospective, observational study. Lancet Respir. Med. 8, 475-481. https://doi.org/10.1016/ S2213-2600(20)30079-5

Zhou, P., Yang, X. Lou, Wang, X.G., Hu, B., Zhang, L., Zhang, W., Si, H.R., Zhu, Y., Li, B., Huang, C.L., Chen, H.D., Chen, J., Luo, Y., Guo, H., Jiang, R. Di, Liu, M.Q., Chen, Y., Shen, X.R., Wang, X., Zheng, X.S., Zhao, K., Chen, Q.J., Deng, F., Liu, L.L., Yan, B., Zhan, F.X., Wang, Y.Y., Xiao, G.F., Shi, Z.L., 2020. A pneumonia outbreak associated with a new coronavirus of probable bat origin. Nature 579, 270-273. https://doi.org/10.1038/s41586-020-2012-7

Zumla, A., Chan, J.F.W., Azhar, E.I., Hui, D.S.C., Yuen, K., 2016. Coronaviruses - drug discovery and therapeutic options. Nat. Rev. Drug Discov. 15, 327-347. https://doi.org/10.1038/nrd.2015.37 